Ssciendo Studia Anglica Posnaniensia 56s1 (2021): 551-577

doi: 10.2478/stap-2021-0012

\title{
UNPACKING THE COMPLEXITY OF GENDER INTEGRATION IN THE U.S. MILITARY USING DISCOURSE ANALYSIS: THE CASE OF SERVICEWOMEN'S TALK AROUND HAVING TO PROVE THEMSELVES
}

\author{
JOANNA PAWELCZYK ${ }^{1}$
}

ABSTRACT

\begin{abstract}
A quasi-idiomatic expression 'women have to prove themselves' reflects various performance pressures and heightened visibility of women functioning in gendered professional spaces as advocated by tokenism theory. It is an example of how discriminatory practice - according to which competent and qualified women entering the culturally masculine professions are explicitly and implicitly expected to work harder for any recognition - gets discoursed in language and becomes a "rhetorically powerful form of talk" (Kitzinger 2000: 124).

This paper explores the question: what is it that U.S. servicewomen functioning in the culturally hypermasculine space need to do to prove themselves?

To this end, qualitative semi-structured interviews with women veterans of the recent Iraq and Afghanistan conflicts are qualitatively scrutinized with the methods of discourse analysis and conversation analysis to 1) identify practices that U.S. servicewomen engage in to symbolically (re-)claim their place and status in the military, i.e., to prove they belong; 2 ) find out how the talk around proving emerged in the course of the conversation and how it was further interactionally sustained and/or dealt with in talk-in-interaction.

The findings of the micro-level analysis - interpreted through the lenses of tokenism and the category of the 'honorary man' - reveal women's complex and nuanced struggle to fit and find acceptance in the military culture of hypermasculinity. They also re-engage with the ideas of tokenism by demonstrating that various acts of proving, reflecting women's token status, may concurrently and paradoxically be a means to earn honorary man status.
\end{abstract}

Keywords: Women; gender; military; qualitative interviews; discourse analysis; conversation analysis.

1 Faculty of English, Adam Mickiewicz University, Poznań; ul. Grunwaldzka 6, 60-780 Poznań, Poland; pasia@amu.edu.pl 


\section{Introduction}

Women can now officially serve in all roles and positions in the U.S. military. Although unofficial, the process of full integration of women in the military was symbolically marked with women's involvement in infantry and special operations units in the conflicts in Iraq (from the year 2003) and Afghanistan (from the year 2010). Officially, however, the process of women's full integration in all military positions and occupations, with no exceptions, started in January 2016 as announced by then Secretary of Defense Ashton Carter in December 2015. It followed the Pentagon's January 24, 2013 announcement removing the combat exclusion policy. However, while it may be claimed that the structural assimilation of women into the military has been accomplished, the question remains whether women service members are also becoming fully culturally integrated (cultural assimilation) into this highly masculinized or hypermasculine ${ }^{2}$ institution in view of the existing "female soldier paradox" (Howard \& Prividera 2004: 89, cf. also Herbert 1998; Mackenzie 2015) which constructs the category 'woman' unfit to perform the tasks traditionally ascribed to the category 'soldier'.

Sjoberg, Cooke \& Neal (2011: 4) caution that gender integration is "about changing the institutions such that standards of what it means to be 'a man' or 'a woman' do not dictate either participation or how such participation is received or interpreted". Prividera \& Howard (2014: 119) claim that the official/institutional changes "may end up being a hollowed out shell of an opportunity in which the ideology can continue to hide" (cf. also Mackenzie 2015). The research has evidenced various stereotypes servicewomen face and their ways of coping with them (see, e.g., Dunivin 1991; Archer 2012; Crowley \& Sandhoff 2017).

The experiences of women entering the 'masculinized' (Connell 2002; Sjoberg 2010) space of the military to a great extent reflect the experiences and struggles of many women who were 'the first' ones breaking into male-dominated professions (Walsh 2001; Shaw 2006; Disler 2008; Foley et al. 2020) and having to claim their place there. Still, it can be argued that the military as a masculinist (or hypermasculine) organization, where traditional masculine practices are socially valued and consequently institutionalized (King 2016), poses a particular challenge for women to be culturally accepted/assimilated. As discussed by Howard \& Prividera (2008) the military as a masculinist organization extensively distances itself from "all expressions of femininity" (2008: 289, see also Moore 1991; Sasson-Levy 2003; King 2017). Studies have shown how military culture and practice subordinate the feminine (e.g., Enloe 2010; Sjoberg 2010; Prividera \& Howard 2014) as well as how women have to adopt and/or draw on symbolically

2 The terms 'masculinized', 'hypermasculine', and 'masculinist' are used as synonyms in the paper. 
masculine characteristics to do being a soldier (Crowley \& Sandhoff 2017; Heinecken 2017; Pawelczyk 2017). Given this, women who want to join military groups join organizations already characterized by hegemonic masculinity (Connell 1987; Carreiras 2006) and/or oftentimes toxic masculinity (Berdahl et al. 2018). The military - in that sense - constitutes one of the most, if not the most, symbolically (culturally) guarded professional space for women to enter and function. This is to say that women's entrance as tokens and thus being a minority in the organization is likely to be met with some form of resistance from men as dominants who constitute the majority in the military (cf. Yoder 1991). As Epstein (1981: 194) argues: “. . . the dominant group may continue to regard women as something different and unacceptable, perhaps tolerated but not assimilated". Recent research, however, identified an important sign of "gender revision" (King 2016: 139) of the armed forces by proposing the category of the honorary man (King 2013, 2016), very relevant to the women war veterans of Iraq and Afghanistan conflicts whose stories are scrutinized in this paper.

This study - framed in the theory of tokenism (Kanter 1977a, 1977b; Yoder 1991) and the concept of the honorary man (King 2013, 2015, 2016, 2017) identifies the practices that servicewomen engage in 'to prove themselves' that emerge from interview interactions. Both direct references to 'prove' as well as its indirect indexing will be interactionally scrutinized with the aim to qualitatively unpack, identify, and ultimately arrive at an understanding of the complex gender dynamics within the U.S. military at the time when women have been structurally assimilated in that institution. The study demonstrates the practices that military women - already being fully qualified and competent - engage in to legitimize their professional status in the hypermasculine organization.

The paper opens with a review of the tenets of tokenism and the concept of the honorary man in the context of women's minority status in the U.S. military and frames the claim 'women have to prove themselves' as an ideologically-laden assumption. This is followed by a presentation of data and methodology. A qualitative study of relevant excerpts of interviews with female servicewomen is offered next, followed by a discussion of findings and concluding remarks.

\section{Women as tokens and 'honorary men' in the military}

The theory of tokenism (Kanter 1977a, 1977b; cf. also Yoder 1991; Yoder \& Perez 2013) allows us to frame, construe, and understand servicewomen's ways of acting and behaving in the hypermasculine space of the military. According to the theory, when a certain group of people in an organization has less then fifteen per cent of representation (e.g., women), they - as tokens and minority members - face certain disadvantages from the majority members (e.g., men, the 
dominants). The theory has been found to be relevant to the military setting as discussed by Yoder (1991) and Perez \& Strizhko (2018).

Overall, women currently constitute about seventeen percent of DoD active duty military personnel (SWAN 2019) - although the numbers differ depending on the military branch - thus their numerical presence oscillates around the token numbers. Based on Kanter's original assumptions (1977a, 1977b), the empirical research showed that "the consequences of disproportionate number of women and men in a workplace" are only relevant for women who function in jobs that are socially and culturally deemed as masculine (Yoder 1991: 178).

As discussed by Yoder (1991) - critically evaluating and extending Kanter's work on tokenism - women's minority status in organizations typically manifest itself by "heightened attention or visibility that exacerbates pressures for them to perform well" (Yoder 1991: 179). In other words, women tokens are somehow compelled to perform at least as well as men and their performance, at the same time, is judged for possible transgressions (Kanter 1977a). Women tokens tend to suffer social isolation from "professional networks" and experience heightened cultural boundaries from male peers as well as tend to function in gendercongruent roles, which limits their opportunities for growth (Yoder 1991: 179). Similar findings have been identified for the military settings (for a summary see Perez \& Strizhko 2018).

Yoder (2002: 5) stresses that women tokens tend not to receive "benign neglect" by the dominants (men) (cf. also Kanter 1977a). Rather both direct and indirect exclusion measures, such as - among others - "insufficient instruction, silence, close and punitive supervision" are taken by majority men to keep the tokens "in subordinated positions" (Yoder 2002: 5). This is in line with tokenism theory predicting that greater numbers of minority group may be perceived as a threat to the dominants who may, in fact, "effectively restructure the workplace to reduce the competitive threat posed by the growing minority" (Yoder 1991: 188; cf. also Shaw 2006).

In line with the above it can be argued then that the growing number of women in the U.S. military will not in itself change the patriarchal culture of the military (cf. Sjoberg 2010) and incoming servicewomen may possibly face new (aggravated) forms of discriminatory practices especially in the early stages of gender integration (cf. Walsh 2001). As Enloe (2017) claims, "patriarchy and its mechanisms are easily adaptable to the new emerging or changing social arrangements", while Mackenzie (2015: 5) claims that officially allowing women to enter combat positions, "served to recover and reshape the band of brothers myth". What is also relevant to the context of the U.S. military is that potential marginalization of women may take indirect and veiled forms of exclusion (Yoder 2002) in view of the overall policy of gender integration that institutionally welcomes women. 
The aspect of performance, so much emphasized in the theory of tokenism, might concurrently be a means for servicewomen to be gradually accepted by men and, ultimately, recognized as "one of the guys" (King 2016: 126). As discussed by King (2013: 16), women's (top) performance and (displayed) competence - key aspects of "professional cohesion" that characterizes the current armed forces - are essential for servicewomen to be accepted by male service members. Thus "in a highly professionalized military culture, as long as a woman can perform, she might be accepted by male colleagues" (King 2016: 132). The honorary man - as King (2015: 383) explains - can be "ascribed to competent, respected female soldiers who are no longer seen in sexual terms". The new cultural category of the honorary man that emerged during the Iraq and Afghanistan conflicts, represents a move away from the slut-bitch binary yet, as argued by King (2017: 314), it is very "narrow". Thus women can be easily reclassified by male soldiers as they continue to function in highly masculinized professional space (King 2016). The analysis presented below demonstrates how servicewomen manage this 'narrowness' during their service.

\section{The ideology behind 'women have to prove themselves'}

This study was motivated by observed reoccurrence of both direct and indirect references to 'proving' and the overarching discourse of 'proving' in the collected corpus of interviews with U.S. service members. This study, unlike most research drawing on the theory of tokenism, is of qualitative character. In particular, it scrutinizes the talk around both direct references to the phrase 'women have to prove themselves' as well as its indirect indexing in interview interactions to identify the practices that servicewomen as a minority group engage in to legitimize their position in the military.

The phrase 'women have to prove themselves' captures one of the consequences of servicewomen's token status in the military, i.e., the idea of being highly visible and standing out and thus pressured to perform at least as well as men or better to be professionally recognized. The idea of 'women having to prove themselves' is normalized looking at both popular and scholarly discourse and as such does not require further elaboration or accounting. It can be found across various non-scholarly (1) and scholarly (2) publications relating to women's presence in the military:

1. "Whichever the case, women may have to go above and beyond the standard to prove themselves and may routinely have their work overlooked until there is an immediate benefit" (Trobaugh 2018: 47) 
2. "As the Marine Corp continues to equalize operational standards for males and females through physical fitness requirements, training, and occupational equity, females have more opportunities to prove themselves equivalent to males" (Brownson 2014: 785).

In linguistic and interactional terms, the phrase, due to its all-encompassing character, i.e., not referring to specific 'women' or specific activities that these women engage in (Drew \& Holt 1988: Kitzinger 2000), has started to function as a quasi-idiomatic expression. It has become "recognizable to most cultural members as taken-for-granted commonplace or emblematic expression of shared cultural knowledge" (Kitzinger 2000: 127-128). Quasi-idiomatic phrases are devoid of ambiguity for interactants and thus do not call for further unveiling in discourse or interaction (Stokoe 2012). Due to their "vagueness and their encapsulation of social norms" (Kitzinger 2000: 124) as revealed in conversation analytic research, quasi-idiomatic expressions when used in interaction are not typically contested by interactants (Drew \& Holt 1988; Potter 1996, but see Kitzinger 2000). This is to say that quasi-idiomatic expressions used in a conversation will not be oriented to as problematic items that require some sort of interactional repair on the part of co-conversationalists.

The phrase 'women have to prove themselves' is an example of how a discriminatory practice - according to which competent and qualified women functioning in culturally masculine professions are expected to work harder for any recognition - gets discoursed in language and starts functioning as "rhetorically powerful form of talk" (Kitzinger 2000: 124). The phrase aptly gives a sense of women's continuing struggle with deeply-embedded essentialist assumptions of who 'naturally' belongs to the military and who needs to make effort to find acceptance and earn their place. In the context of the military, the quasi-idiomatic phrase 'women have to prove themselves' constitutes an ideological assumption as women joining the military already possess the necessary skills and competencies to do the required jobs. In other words, they are competent and qualified yet defy the dominant sociocultural expectations for women (Kendall \& Tannen 1997). The overarching dominant/hegemonic ideology of masculinity characterizing the military 'others' servicewomen at their very entry point to the institution, (symbolically) requiring from them some sort of orientation to the hypermasculine space in which they function.

The qualitative micro-analytic study presented below unpacks the quasiidiomatic phrase 'women have to prove themselves' by scrutinizing servicewomen's interview accounts. It identifies the practices of 'proving' as well as, how, and in what situations servicewomen perform 'proving that they belong' to the military. Before the analysis proper, data and the analytical apparatus will be detailed. 


\section{Data and methodology}

In this article I discuss selected data from a bigger project on gender ideologies and women's position in the U.S. military. The project comprises three subsets of data: (i) archived interviews with women and men war veterans of the recent Iraq and Afghanistan conflicts, (ii) semi-structured in-depth interviews conducted by the author with women and men currently serving in the military as well as the veterans of the Iraq and Afghanistan conflicts, and (iii) semi-structured indepth interviews conducted by the author with male and female students and faculty members at one of the U.S. military service academies. The project has received required ethical approvals.

Data used for this study are six interviews with women war veterans of Iraq and Afghanistan conflicts and one with an active duty military woman. Four interviews were taken from Women's Memorial Foundation Oral History Program (https://www.womensmemorial.org/oral-history/detail/?s=about-ouroral-history-program) and one interview from the Library of Congress Veterans' History Project (https://www.loc.gov/vets/). ${ }^{3}$ Two interviews used in data analysis - one with a woman war veteran and one with an active duty military woman - were conducted by the author. Altogether ten data extracts are analyzed. Both women veterans and current active military duty are included in the study to give voice to women's experiences at different stages of their military careers. As a qualitative study, the analysis foregrounds women's voices to better understand their experiences of serving in the U.S. military (cf. Reinharz \& Chase 2001; Bonnes 2017) by scrutinizing servicewomen's perceived "experiences of gender" (Eckert \& McConnell-Ginet 2003: 47). All interviewed women serve(d) in the Army. The names of the servicewomen have been changed and any personal details that could reveal their identity have been removed.

A close qualitative analysis justifies the number of relevant data extracts used in the study as the underlying idea behind a discourse analytic study is to "make sense of or interpret phenomena in terms of the meanings people bring to them" (Denzin \& Lincoln 2000: 3). In line with the tenets of qualitative discourse analysis, where validity relates to the level of detail of the analysis, I will be able to discuss a few extracts. The presented accounts, however, represent the experiences of many other women who I talked to or whose stories have been deposited in the Women's Memorial Foundation Oral History Program or in the Library of Congress Veterans' History Program.

3 The interviews from the Women's Memorial Foundation Oral History Project (not available online) and the Library of Congress Veterans' History Project (available online) do not specifically focus on the relevance of gender but cover a number of personal and professional issues related to being a (deployed) service member. The interviews selected for the project data set, however, cover themes referring to how gender may matter in the functioning of the U.S. military. 
The orthographic transcripts of the interviews - showing the content of the interviews in terms of what was said by the interlocutors - available from Women's Memorial Foundation Oral History Program and the Library of Congress have been supplemented with more detailed interactional symbols following Jefferson (2004) to convey a better sense of the complex interactional dynamics of the interview discourse. Another reason for a more detailed yet simplified Jeffersonian transcription was the fact that the analysis focuses both on what as well as how of the interaction in accordance with the tenets of discourse analysis (Antaki et al. 2003)

The interviews used in the study are analysed with the methods of discourse analysis (DA) (Lester \& O'Reilly 2016) and - as pointed out above - the focus falls not only on what is talked about but also on "what is analytically sayable about the participants' talk" (Kitzinger 2000: 123). DA is based on the assumption that any "discourse exhibits recurrent patterns" (Herring 2004: 342) and thus the role of analyst is to identify them. It also assumes that speakers make choices about how to convey and construct their experiences (Herring 2004). In particular, CA as one of the many frameworks within broadly defined DA, via fine-grained analysis of interactional details, allows us to capture various actions that talk is performing. The focus of CA is then on "talk rather than language" (Gardner 2004: 262). Consequently, more than orthographic transcription of the data and its analysis allow us to identify the "participants' reasoning, assumptions and beliefs" (Ostermann 2017: 351) as well as the complexities of one's experience. The value of DA and CA in researching social phenomena lies in, among others, detailing how interaction participants construct social phenomena and their experiences by way of talking, how they invoke and align with but also challenge and contest various social issues in discourse and interaction. The current study looks into language use and interaction to demonstrate the complexity of the phenomenon of gender integration in the U.S. military by finegrained analysis of servicewomen's talk around having to prove themselves.

The analysis to follow is divided into two parts. Part One (six extracts) examines the interview extracts in which a question (loosely) related to women's minority status in the military was posed by the interviewer. Building on Goffman's (1959) distinction between the expressions given vs. given off, Part One of data analysis focuses on the interviewees' given responses, i.e., their explicit orientation to the question that specifically invoked women's token status in the military. Part Two of the analysis (four extracts), on the other hand, examines the extracts in which the question posed did not relate to women's minority status in the military, yet servicewomen invoked the talk around their 'proving themselves' in the response(s) to follow. Thus the talk around 'proving' was somehow given off in the process of orienting to the interviewer's question. Part Two of the analysis shows how issues around gender emerged organically in 
the interview when the interviewees were not prompted about it (cf. also Britton 2017). Such refocusing of the interview on the category of gender on the part of servicewomen evidences its salience and relevance in how they perceive and report on their functioning in the military.

5. Data analysis: Unpacking the talk around 'proving' in interview interactions

\subsection{Part One}

In the six extracts discussed below, three women war veterans were explicitly asked to relate to their minority status in the military.

In Extract 1, Janet, a female war veteran of the Iraq conflict, gives her account of how she was earning respect as a female service member in the masculine space. The question posed by the interviewer in lines 01-02 presupposes (Heritage 2010) women having to earn respect when joining the military.

\section{Extract 1}

\section{Janet}

01 I: Have you you ever had any trouble soliciting or generating

02 respect as a woman in uniform in a field that's predominately male?

$03 \mathrm{~J}$ : Sure you would think that after

04 I: $\quad$ // maybe give an example

$05 \mathrm{~J}: \quad 22$ years of service in the rank on my collar that you would demand that

06 automatic respect and I don't think it matters if you're a private or a general if 07 you're a woman you always have to prove yourself first to where a man he 08 comes into unit and he is given the benefit of the doubt until proven

09 otherwise. On the other hand if you're a woman, you have to prove yourself 10 before you're considered a part of the team and you would think that would 11 change as you go up in rank but it doesn't (.) it really doesn't and I think if you 12 expect that you won't be ever disappointed or misled because it can be a 13 little (.) it can be frustrating because you would think that you wouldn't have 14 to start over every time but you do it's just a fact.

Janet immediately agrees ("sure", line 05 ) with the presupposition stated by the interviewer that military women as tokens in the organization need to earn respect functioning in the masculine space. Janet's account reveals the complexity of the processes of military women 'proving themselves'. According to Janet, women in the military are continuously engaged in the process of proving themselves regardless of their rank. This is to say that the process and symbolic acts of showing that women belong to the military do not characterize the initial stages 
of their military career only ("I don't think it matters if you're a private or a general", line 06). 'Proving' in the case of servicewomen emerges as an incessant process as discursively marked by means of extreme case formulation (the use of "always" line 7; Pomerantz 1986). The item 'always' receives an extra emphasis in Janet's description, further evidencing women's perception of a need for constant involvement in demonstrating their skills and competencies.

The position of men is constructed as starkly different (lines 07-09) since male service members do not need to get involved in the process of demonstrating their skills and capabilities. Servicemen as dominants are instantly accepted as professionals in contrast to women who - an echo of the statement in line 07 - need to show their abilities before symbolically becoming a member of the team (line 10). Janet, in lines 10-11, reiterates how being promoted in the case of servicewomen does not eliminate the necessity of further proving themselves, thus working harder for recognition as a minority This is reinforced by the repetition of "it doesn't (.) it really doesn't" (line 11), thus building a strong case of performance pressures existing for military women regardless of their ranks.

Janet in lines 11-14 talks about how servicewomen should accept constant demonstration of their skills and capabilities at all stages of their careers as a prevention of possible frustration and misgivings. This can be construed as a way for military women to make it in that professional space.

In Extract 2 lines 01-03, Nancy, a female war veteran of the Iraq conflict and the only female in her platoon, recounts how while being deployed she was struggling to be respected by her male colleagues. The interviewer in line 04 asks for the exemplification of her struggle.

\section{Extract 2 \\ Nancy}

$01 \mathrm{~N}$ : ...I wanted to be treated with the same respect as the next guy, but it's it's

02 sometimes they still saw me as their sister type and it was hard for me to

03 relay to them how exactly to communicate with me.

04 I: Can you give me like an example?

$05 \mathrm{~N}$ : Okay, um, we did a large project, we built an airport bigger than $\mathrm{X}$

06 and, um, during the times where we were pulling rebar and um

$07 \quad$ tying rebar and cutting rebar and lifting it and putting it in the framework and

08 pouring concrete, there were times where physically I was unable to lift

09 something (.) but I still did (1.0) a:nd there were times where um physically I I

10 was having a very difficult time pouring concrete cause it was just very heavy

11 um but I still did and there were times where my Kevlar was so heavy on my

12 head (.) that I wanted to take it off but I left it on. Um, but even though I had 
so many of those times where physically I was pushing it beyond my capability, those times when I said okay, I need a break, it was almost like um viewed (.) derogatively, like I was weak. But I had my platoon sergeant actually acknowledge this to me towards the end. He said, you know out of everyone in my platoon you put in 150 percent and some of these guys got by with 50 percent. I just want you to know that I know that (1.0) and that you worked harder than any female in our unit, because the other females had less physically exhausting jobs like driving a vehicle or office work and I was out there doing all the heavy labor and stuff with every other guy.

In line 05 Nancy embarks on a mini story telling of building a big airport during her deployment, describing the tasks she was involved in (lines 06-08) and giving a sense of the difficulty of the work she was engaged in. Nancy's account in lines 08-12 allows us to identify servicewomen's practices around 'proving themselves' as a manifestation of their token status. Nancy projects in her account how she was performing the tasks which almost exceeded her capability, including lifting heavy objects, pouring concrete and keeping her heavy Kevlar on, yet she persevered in pursuing them. In her words she was "pushing beyond her capability" (lines 13-14).

Nancy's mention of what happened when she needed to rest (lines 14-15) evidences how the category of honorary man, that Nancy might be aiming to accomplish, is an "exceptionally narrow category for women to sustain" (King 2015: 385). Her taking a break received heightened attention from fellow service members and was perceived negatively, almost likened to her being "weak" (line 15). We can observe Nancy's emotional stance in talking about this experience as marked with the discursive items "like", "um" (line 14), and a mini-pause (line 15). Nancy's perception of heightened attention when taking a break evidences hyper-vigilance of servicemen as far as servicewomen's potential momentary non-adjustment to the ongoing work is concerned. This is to say that all her hard (and adequate) work so far did not matter and was symbolically invalidated as soon as Nancy needed to take a rest.

Nancy also recounts the platoon sergeant's reaction to her great effort and dedication (lines 15-21). The sergeant singled out and validated her work as a woman who exceeded the performance of her male colleagues. This could be a sign of Nancy being in the process of accomplishing honorary man category. Nancy's mention of the sergeant's remarks demonstrates the importance of the recognition and validation of servicewomen's work and effort by their superiors. It is interesting how Nancy uses the phrase "every other guy" (line 21) to emphasize that she was involved in exactly the same tasks as men. This to say that 'proving' entails women being engaged in the same jobs as men are and concurrently men functioning as the reference category. 
In Extract 3, the interviewer, in lines 01-02, brings up the interviewee's (Jessica) previous mention of the military being a masculine territory. Jessica is an African American woman, a veteran of the conflict in Afghanistan.

\section{Extract 3}

\section{Jessica}

01 I: Does the military continue to be a masculine territory? [...] you said earlier

02 that you can feel that. How did you feel that it was masculine?

03 J: I was very strong and doing everything I followed through everything I

04 needed to do that's why I got promoted as fast as I did that's why I was able

05 to, you know, stay as long as I did but some things were just like dude I'm a

06 woman I can't do some of the things that you can do I just cannot physically

07 but you know some men they just don't care and a lot of men would just

08 look at the women like they're just there for you know entertainment,

09 amusement even though they're soldiers. You have to be strong you have to

10 be a strong woman in the military to deal with some of the stigmas of being

11 in the military uhm especially being a minority woman you have to work triple

12 as hard as anybody else because not only are you, you know, minority you're

13 a woman as well so you got two things coming against you (1.0) so:: you just

14 have to move just move you $\uparrow$ know

Jessica, in lines 03-05, gives a brief account of her successful army career. She builds her account by relying on extreme case formulation by using "everything" twice (line 03; Pomerantz 1986). This constructs Jessica as a hard-working and dedicated service member and conveys the idea that there is no place for a mistake for servicewomen (as tokens) in their military careers.

Jessica's account gives evidence to servicewomen being subjected to men's hyper-vigilance as her inability to perform certain tasks was met with men's disregarding attitude (lines 05-09). This echoes Nancy's account (Extract 2) where any accomplishments of a servicewoman are remembered until the time she is unable to perform a task or just needs to take a break. In particular, in Jessica's perception, servicewomen who were unable to do certain jobs would be made fun of and treated by men as a source of amusement. It is important to emphasize that these were occasional situations yet received a strong negative reaction from men. Jessica's reference to women as "they're soldiers" (line 09) makes an appeal to view women serving in the military in terms of their professional identity. As her account demonstrates, servicewomen are viewed and evaluated in the professional setting of the military through their gender thus their minority status is foregrounded. Jessica also refers to stigmas that women as tokens face in the military and the need to take a proactive approach to them (line 10). All in all, in Jessica's account, servicewomen receive heightened attention and visibility regarding their occasional failings. 
In the last part of her account, Jessica gives a sense of the challenges servicewomen face on a daily basis. Being an African American woman, she brings the category of ethnicity into the discussion (line 11). She begins this part of her account with the theme of women having to be strong (repeated twice) then referring to minority women as functioning in particularly difficult circumstances. Gender and ethnicity are thus brought up as intersecting oppressions for women of color in the military (cf. Collins Hill 2000). As a result, they "have to work triple as hard as anybody else" (lines 11-12). It can be claimed then that 'proving' for minority women in the military takes the form of doing more tasks than an average service member, including non-minority women. Jessica frames the categories gender (being a woman) and ethnicity as two potentially problematic entities for the professional identity of a service person. The phrase used by Jessica "you just have to move just move" (lines 13-14) concerning minority women in the military echoes the idea of women always being on heightened alert to react to whatever is going on in the here-and-now of the situation.

In Extract 4, lines 01-02, Jessica is asked about her potential familiarity with stories or jokes circulating in the military in which women are objects of laughter.

\section{Extract 4 Jessica \\ 01 I: Do you remember any jokes or stories that were told in the military, the 02 stories in which women were made fun of? \\ $03 \mathrm{~J}$ : No: not not really being made fun of uhm it wasn't like juvenile like that uhm 04 (3.0) it wasn't like that it was just more of like you can just feel you 05 would just know how they would move and how they would act and you 06 know how they would talk that you just knew that ok uhm they think I'm just 07 stupid like I'm just here being a woman and that's it so you just had to show 08 that to people that you're not (.) just that.}

Jessica in lines $03-07$ attempts to convey a sense of how potentially derogatory attitudes toward women in the military are conveyed. The interactional items "uhm" and pauses (lines 03-04) index her expressive caution in describing a situation that is emotionally delicate (Silverman 2001). Jessica indirectly states that derogatory comments targeting women were not overt; rather her description in lines 03-06 indicates a great degree of covertness and indirectness in how women were made fun of. This is in line with Yoder's (2002) claim that exclusion of token women may be performed in subtle manner (cf. also Lazar 2014). Interestingly, in Jessica's account, the deprecating attitude toward women could be inferred from a whole spectrum of men's behavior including the way they 
moved, acted and talked. This points to the overall culture of gender microaggression (Sue 2010) characterizing the professional space of the military.

Repetition of the verb "know" (lines 05 and 06) signifies that the ability of decoding men's behavior as derogatory toward women constitutes an aspect of women's covert socialization in the military. This is to say, part of your professional experience acquired as a servicewoman is to be able to identify the covert belittling acts and act/respond accordingly.

As Jessica explicates in lines 06-07, military men perceive servicewomen in terms of hegemonic/emphasized femininity (Connell 1987) in the here-and-now of the specific situation (the use of the Present Continuous tense: "like I'm just here being a woman", line 07). This is to say that the characteristics of dominant femininity - rather than professional ones - prevail in how women are thought of and approached. In Jessica's account, in military men's perception, there is an incongruity between being a woman and being a military service member thus being "stupid" (line 07) in the military context is linked to "being a woman" (line 07).

The practice around 'proving' can be identified in lines 07-08. According to Jessica, servicewomen need to demonstrate a disavowal of dominant feminine characteristics and consequently exhibit more of dominant masculine features to show they belong (cf. Crowley \& Sandhoff 2017). In other words, servicewomen as tokens need to demonstrate that they are and do more than 'being a woman'.

In Extract 5, in lines 01-03, the interviewer poses the question to Jessica that indexes assumptions behind 'women proving themselves'. The focus of the query is on men's attitude to women who demonstrate with their actions that they are as good as their male counterparts.

\section{Extract 5}

\section{Jessica}

01 I: what happens if you're able to carry you know all the weapon you

02 mentioned you're physically strong and you're very good and you're

03 basically as good as men or even better uhm

$04 \mathrm{~J}: \quad \mathrm{OH}$ men get jealous oh they get jealous (.) oh when I went on mission

05 OH MAN when I went on mission there were men who could not make it

06 through the mission but I did and they were embarrassed like super

07 embarrassed because not only was a woman I'm a sma:ll woman I'm

08 carrying all the satchels like you, I'm walking through the hills just like you,

09 you can't make it but I can, oh yeah men look at you, for the majority

10 they're like it's like oh shoot you gotta watch out for her 'cause she thinks

11 she is one of us she thinks she is better than us or something like that. 
Jessica, in lines 04-09, in an animated manner (e.g., the use of the item "oh" and greater loudness) describes her experiences of one of the missions during which she excelled and, unlike some men, was able to complete it. In particular, she emphasizes her being a small woman and still being able to make it. Jessica's account demonstrates men's hyper-vigilance to servicewomen's performances which is treated as a benchmark to assess men's performance. The male gaze accompanies women whatever they do and men's assessment of women's performances follows.

As projected in Extract 5, the ubiquitous men's hyper-vigilance does not get translated into specific verbal commentary. Its power lies in its implicitness. In line 09 , Jessica professes "the men look at you" followed by a number of assumptions of what that look tends to convey. Thus Jessica, who demonstrated during the mission that she is as good as men, will attract more of men's attention/vigilance due to her superb performance which - in men's assessment - may indicate crossing the gender boundaries in the military. Men as the reference category in the military can be observed in the use of the phrases "she thinks she is one of us" (lines 10-11) and "she thinks she is better than us". While the first phrase captures a possible resistance to accepting women as equal and normalizes men/male standard in the military, the latter re-emphasizes the difference between men and women in that professional setting and speaks to men as the reference category. "She thinks she is better than us" aptly shows the difficulty of gaining the honorary man status by women despite demonstrating top performance.

In Extract 06, Eva, a current Army member, is asked in line 01 whether she had any female instructors during her basic training and following her no-gap-nooverlap response in line 02 , what these instructors were like (line 03 ).

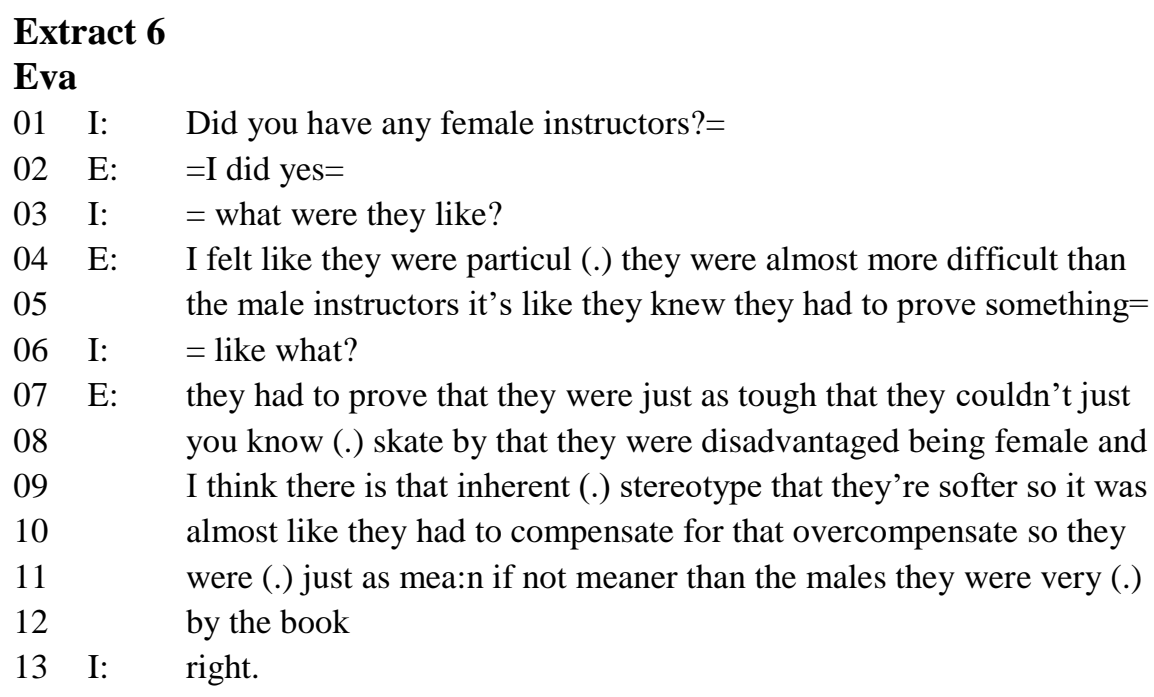


Eva, in her response in lines $04-05$, constructs her female trainers as more demanding than the male ones and refers to her female instructors as acting on the unspoken assumption that "they had to prove something" (line 05). It is interesting that Eva in her account refers to the unspoken covert understanding that the female instructors were aware they had to demonstrate their competence ("it's like they knew", cf. also Jessica's account in Extract 4). The interviewer pursues the theme of 'proving' with the question in line 06 to detail what it was that the female instructors had to prove.

Eva describes her female instructors as being "tough" (line 07) and "mean" (line 11) and the benchmark for that assessment are male instructors (line 11). Being 'tough' and 'mean' become glosses for 'proving' in Eva's account. The idea of female instructors having to prove themselves is attributed to the overarching (yet unspoken) stereotype of women being "softer" (line 09) and women taking measures to challenge it. Eva points to the fact that women need to do much more, i.e., to "overcompensate" to show that they do their job. 'Proving' for basic training female instructors also takes the form of following the rules very closely (line 11-12).

The qualitative analysis of the six extracts presented above allowed us to identify the complexity and situatedness involved in the process of servicewomen having to prove themselves. The idea of 'proving' is a consequence of women's token status in the military.

The analysis demonstrated that the process of proving is incessant and consequently not contingent on a woman's rank. In other words, it never stops. Servicewomen's practices around proving involve maximizing their physical capabilities in order to keep up with men or when possible, outperform them. Servicewomen in their accounts also underlined the importance of performing the same tasks as men do in their acts of proving themselves and the situated necessity to disavow the feminine characteristics as well as following the rules very closely. Minority women experience particular performance pressures due to intersecting gender and ethnicity categories. Women also prove themselves when they do not fail, even occasionally, as any potential sign of even anticipated underperformance leads to symbolic erasure of women's previous accomplishments. This is to say the fact that servicewomen are under constant hyper-vigilance of their male colleagues manifests itself - among others ways in women's overt comments on men's recognition of their efforts. The hypervigilance, similarly to the performance pressures on female service members, tends to take the covert, implicit form. Servicewomen emphasized that proving oneself is necessary to claim their place on the team. This is very different from men's experiences as they are given the benefit of the doubt. Servicewomen's top performance may earn them the status of the honorary men, signifying acceptance from their male colleagues, yet that status needs to be constantly renewed. 


\subsection{Part Two}

Part Two of data analysis examines the relevant data extracts from four women, in which the theme of servicewomen 'having to prove themselves' emerges in the midst of the interviewees' responding to a question not strictly related to women's minority status in the military. Such interactional behaviour on the part of servicewomen, i.e., reorienting the course of the interview to the stories of women's token status in the military, demonstrates the embeddedness of servicewomen's military experiences in the category of gender. This is to say that gender matters in the military as far as servicewomen are concerned and - as evidenced in their accounts - it becomes an ominirelevant category for women serving in the military (e.g., Weatherall et al. 2010).

In Extract 7, line 01, Dorothy, an Army war veteran of the conflict in Iraq, is asked a question regarding her emotional state in connection with having lost one of her hands when she was deployed.

\section{Extract 7 \\ Dorothy}

01 I: When was the last time you did get emotional about not having (.) your $\uparrow$ hand

02 D: [...] I found myself oftentimes at midnight just wan' just breaking down. It

03 would be ten to fifteen minutes then I would feel better but it was good to

04 get it out 'cause I was being so tough all those other weeks and days just

05 trying to prove to people that (.) you know I'm tough because I was in an

$06 \quad \mathrm{X}$ company (.) so you know they're they're the cream of the crop

07 (laughter) you know (.) a bunch of guys so: it felt good just to let it out a::nd

08 I don't get too emotional now but I have my mood swings but (1.0) that's

09 that's everybody with hands or no with no hands.

Dorothy, in lines 02-04, describes how she regularly experienced emotional difficulty related to having lost her hand. She, however, does not view these experiences negatively. On the contrary, her emotional outbursts are welcomed since when deployed she did not let herself be open with her emotions. In line 04, Dorothy starts refocusing her account on being a woman in the military and thus brings gender into the conversation. In line 05 she uses the phrase "prove (oneself)" which, in her account, relates to controlling one's emotions and thus "being so tough" (line 04). As Dorothy explicates, she had to be in control of her emotions being part of the elite company (line 06) where her actions, as a token woman, were particularly scrutinized. In describing her behaviour when deployed and being a member of the elite company, Dorothy uses the intensifier "so" "so tough", line 04) and extreme case formulation "all those other weeks and days" 
(line 04) to give a sense of the extent to which and time she spent on demonstrating that she is a legitimate member of the company despite her acquired skills and qualifications. Other interactional items in Dorothy's account such as mini-pauses (lines 05, 06, 07), discourse marker "you know" (lines 05, 06,07 ), and laughter (line 07) indicate expressive caution in describing a situation that is emotionally delicate (Silverman 2001).

Interestingly, in line 07, Dorothy juxtaposes the previous reference to her male colleagues "the cream of the crop" (line 06) with a quasi idiomatic phrase "a bunch of guys" to indicate the masculine context in which she had to operate and struggle to be a part of the team.

In Extract 8, Nancy, is asked by the interviewer (lines 01 and 03) whether she is able to talk about her deployment experiences with her fellow service members. The question-answer sequence between the interviewer and Nancy follows a nogap-no-overlap sequence, as indicated by the equal signs (Sacks, Schegloff \& Jefferson 1974) thus demonstrating a good alignment between the interacting parties and thus Nancy being willing to talk about her experiences.

\section{Extract $8^{4}$}

\section{Nancy}

01 I: And are you able like to talk to other people from your unit that are back?=

$02 \mathrm{~N}:=$ Oh yeah=

03 I: =Like about even going through that process?

$04 \mathrm{~N}$ : Yes. I've I've had more physical issues than I've had emotional issues

05 since I've been home, and those physical issues have made some emotional

06 issues a little bit I'm also the only female in my platoon, and I was for most of 07 my deployment, so that was hard as well uhm a:nd (1.0) yy it's it's hard as a 08 female, and especially being the only female in a platoon that is all males uhm 09 to to prove yourself to prove that you're capable of leading men, to prove 10 that you have the same skill level, if not better perhaps not the same strength 11 level but what does strength matter when you can use your brain.

Nancy, in lines 04-06, attributes her emotional issues to various physical problems she developed following her deployment. In line 06, she changes the topical focus of the exchange by bringing up the issue of being the only woman in her platoon and from that moment her account focuses on that aspect of her military experiences. She underlines the difficulty of being not just a woman in the military but points to the importance of the number of women as it was a particular challenge for her to be the only female. She discursively marks it in

$4 \quad$ A part of Extract 8 was also discussed in Pawelczyk (2017). 
(line 07) by using the adjective "hard" twice preceded by some disfluency ("yy") and a pause indicating some degree of emotionality involved in her disclosure. Her status as the only female is again echoed in line 08 thus showcasing the difficulty of that situation for her.

The phrase "prove yourself" is used by Nancy in line 09, then echoed twice (line 09), followed by detailing what proving oneself entails. According to Nancy women need to demonstrate their capability of being in charge of men (line 09) and possessing the same or potentially better expertise than men. Nancy does not assume servicewomen need to be as physically strong as their male colleagues since they can make up for it with their intelligence.

Extract 9 features Tiara, an Army war veteran of the war in Iraq, who is asked in lines $01-03$ about her most memorable events from the early stages of her career.

\section{Extract 9}

\section{Tiara}

01 I: What are your most vivid memories of the early days of your career

02 leading up to [unintelligible]. What were some of your assignments,

03 responsibilities that went into that period of time?

04 T: Sure I remember my first job as a platoon leader a:nd I had a platoon, an

05 aviation platoon of pilots and of course as a Second Lieutenant starting out,

06 you really want to prove yourself and, you know, I think one of my earliest

07 memories was going on a road march with my unit and they decided the

08 Commander just wanted to go on a road march I don't know why. We

09 usually don't walk much we usually fly but he wanted to go on a road march,

10 and I, wanting to prove myself, I grabbed the M-16 machine gun and carried it 11 and it must have weighed 120 pounds, soaking wet trying to carry this giant 12 machine gun and because I was platoon leader I didn't actually march in

13 formation, I ran up and down between the two columns a:nd it was hard, you

14 know, but the whole time I just kept whistling, you know to convince

15 everybody I was fine and at the end of it I don't think I got out of bed for two

16 days because I was so: sore but afterwards some of my guys came up to me

17 and said, you know, that was pretty amazing that you did that for the whole

18 road march and you ran up and down and carried that thing and I have a lot

19 of respect for you for that so: that's probably my earliest memory.

20 I: And I'm just wondering what kind of challenges you face in trying to be one

21 of the $\uparrow$ guys

Tiara, in her account, uses the phrase "prove oneself" twice (lines 06 and 10). In the first case Tiara uses the phrase in connection with her newcomer status as a Second Lieutenant. She does not make her gender relevant at this point of 
her account instead highlights her professional identity as to why one needs to demonstrate his/her competencies in the military (but see Janet's account, Extract 1).

In line 06, Tiara embarks on narrating her experience connected with the road march. In line 10, she brings up the phrase "to prove oneself" followed by unveiling what the proving actually entailed, concurrently refocusing her account on the theme of being a woman in the military. This time the phrase takes on gendered meaning, i.e., it relates to Tiara's demonstrating her competencies as a female Second Lieutenant as indexed by her reference to her male colleagues' (potentially her subordinates') evaluation of her performance on the road march. This points - again - to Tiara's perception of male service members' hyper-vigilance when it comes to servicewomen's actions regardless of their ranks (see Janet's account, Extract 1). Tiara's practices around proving herself as a servicewoman take the form of displaying her superb physical skills by carrying a heavy weapon (which was not a requirement in the task to be performed) and running with it during the march. Tiara provides a sense of a challenge in performing this task by referring to her being "soaking wet" (line 11) and admitting how tough it was (line 13). At the same time, however, in the spirit of 'proving', Tiara did her best to downplay and hide her physical exhaustion (lines 14-15) to her platoon members. Her disclosure in lines 14-15 is preceded by the discourse marker "you know" indexing the upcoming personally sensitive and delicate content (Pawelczyk 2011). Tiara's status as a token in the organization is neatly constructed when she recounts the reaction of some of her (male) subordinates to what she did (lines 16-19) which takes on the form of evaluation of her action: "that was pretty amazing" (line 17), "I have a lot of respect for you" (lines 18-19).

In Extract 10, Nora, an Army veteran of the war in Iraq, is asked in line 01 to give some background about her career as a master parachutist.

\section{Extract 10}

\section{Nora}

01 I: And master parachutists, tell me a little bit more about that.

$02 \mathrm{~N}$ : It was just youth I guess. As a master parachutist you can do

03 what is called chase jumps a:nd I made it my life to network to get

04 parachute jumps. I would jump every Sunday I would jump with every

05 service, the Air Force, the Navy, Marine Corps, and I would try to

06 jump as much as I could. You have to have 65 jumps to be a master

07 parachutist and then a certain number of night jumps a certain number

08 of jumps with units called tactical, mass-tactical and I did whatever I could

09 to attain that. It was kind of a, well (.) a badge of honor if you want to put it 
that way because as a woman, if you don't have some of the things to be competitive, you already, you're fighting from the bottom up so once they see that you have master wings at least you can have one sign of recognition when you have to go into units with fairly hard-core males.

Nora responds to the question by describing her complete dedication in pursuing the military career of a parachutist (lines 02-09). She relies on a number of discursive items to construct her perseverance, such as: "every" (line 04, used twice), the phrase "as much as" (line 06), the item "whatever", with extra emphasis (line 08). Similarly to other servicewomen, she extensively relies on extreme case formulation (Pomerantz 1986) to mark her overt effort in her struggle be symbolically accepted in the military.

In line 09, Nora, refocuses her account on her identity as a female military parachutist thus bringing the token narrative into the conversation. She clearly emerged from her description in lines 02-09 as a top-notch professional yet when referring to her accomplishments as a "badge of honor" (line 09) she hedges it with the items "kind of" and "well" as if undermining her previous account.

As accounted for by Nora, determination and perseverance is a part and parcel of being a military woman and almost a requirement when serving with "fairly hard-core males" (line 13), i.e., in an institution where hypermasculine culture prevails (Howard \& Prividera 2008). As a woman, Nora, had to demonstrate her superb professional skills as a way to be recognized by her male colleagues (line 12) as a team member. The phrase referring to military women "fighting from the bottom up" (line 11) indexes servicewomen's minority status and thus the related performance pressures. 'Proving' herself in the case of Nora took the form of accomplishing the title of the master parachutist to gain recognition in the culturally hypermasculine unit.

Part Two of data analysis showed the salience of the theme 'proving oneself' for servicewomen as they topicalized their 'proving' in the midst of answering the question not related to their status of servicewomen. In other words, talk about the military in general provoked their steering the conversation toward women's status as tokens in the military. Servicewomen's stories and examples testify to the overarching yet unspoken expectation that female service members although being fully qualified and competent - will overtly demonstrate that they can do the job of a service member, who symbolically, is still male. As narrated and accounted for by servicewomen in Part Two of data analysis, the practices around 'proving' entail restraining emotions, hiding and downplaying physical exhaustion when performing physically straining tasks. Servicewomen also seized the opportunities to make their male colleagues notice their dedication. 'Proving' also involves military women's determination and perseverance in 
performing their tasks and (ultimately) gaining men's overt recognition. That recognition indicates servicewomen's acquiring the status of the honorary men and thus acceptance from their male peers. Just as in Part One of data analysis, Part Two also evidenced military men's hyper-vigilance to what their female counterparts do and, more importantly, how they perform the tasks at hand.

\section{Discussion and conclusion}

This qualitative study revealed servicewomen's practices of 'proving' themselves as a consequence of their token status in the organization where men are dominants and culturally masculine ways of acting have been the norm. Women's accounts also speak to the narrowness of the concept of the honorary man as their top performance was not always recognized by their male colleagues to allow them to feel accepted and be 'one of the guys'.

Both the token status and the honorary man category revolve around performance. The talk around 'proving' reveals a delicate balance between servicewomen's seeking acceptance through (over-)performance in the hypermasculine space yet still facing rejection from male counterparts. The analysis demonstrated how servicewomen's single manifestation of even justified weakness significantly undermined their previous accomplishments in the eyes of the male colleagues. This speaks to a serious challenge for the cultural assimilation of women into the military where a woman's superb performance and competence do not secure acceptance from male colleagues.

'Proving oneself' typically does not constitute a response to an overt and direct pressure. Rather the performance pressure is conveyed in subtle, implicit and often unspoken manner. Stories of 'proving themselves' by servicewomen evidence that men tend to function as the reference category and the male standard has been normalized. By discursively unpacking the stories of 'proving oneself', the analysis showed that 'proving' is a multifaceted and nuanced practice. Physicality occupies a central position in servicewomen's 'proving' practices. Thus they strive to maximize their physical performance - a requirement to gain the status of the honorary man - but also downplay the accompanying physical exhaustion. In servicewomen's perception, their performance is typically scrutinized by male gaze and thus they receive either positive (overt) or negative (covert) recognition for it. In general, there is an atmosphere of perceived male hyper-vigilance when it comes to women's actions. Performing in a hypermasculine space, servicewomen also tend to restrain emotions as their expression may index emphasized femininity which overall they should try to be distanced from. 'Proving oneself' also involves seizing the opportunities to demonstrate one's skills and abilities in the here-and- 
now of the specific situations, i.e., going above and beyond the (male) standards. 'Proving' - as evidenced in servicewomen's accounts - is not limited to a single occasion. It is a never-ending process thus servicewomen perform acts of proving throughout their military careers irrespective of their already accomplished ranks.

As discussed above, the fact that servicewomen have to 'prove themselves' is an example of dominant masculine standards that still prevail in the U.S. military despite the extensive gender integration process in place. This is to say that in cultural terms, gender continues to matter in the U.S. military. As the analysis demonstrated, servicewomen brought up stories of what it is like to be a woman in the U.S. military even when the question posed did not relate to issues of gender. The question and challenge remains how we go about changing the cultural assumptions regarding the category of gender in the military so that qualified and competent servicewomen, entering the U.S. military in greater numbers, encouraged by changed policies, just like their fellow men, are given 'the benefit of the doubt until proven otherwise'.

\section{Ethical statement}

The project was conducted according to the guidelines of the Declaration of Helsinki, and approved by the Institutional Review Board of the University of Maryland College Park (date of approval: November 26, 2018). Informed consent was obtained from all subjects involved in the study.

Transcription conventions:

I - interviewer

.? - punctuation for intonation

$::-$ elongation of the sound

(3.0) - timing in seconds

(.) - a pause of less than a second

Here - increase in emphasis

BAD - capitals indicate even greater loudness than underlined words/sounds

// - interruption

$=-$ neither gap nor overlap in talk; latch

$\uparrow-$ rising pitch or intonation

$\mathrm{X}$ - material removed 


\section{REFERENCES}

Antaki, Charles, Michael Billig, Derek Edwards \& Jonathan Potter. 2003. Discourse analysis means doing analysis: A critique of six analytic shortcomings, Discourse Analysis Online $1(1)$.

Archer, Emerald M. 2012. The power of gendered stereotypes in the US Marine Corps. Armed Forces \& Society 39(2). 359-391. DOI: 10.1177/0095327X12446924

Berdahl, Jennifer L., Marianne Cooper, Peter Glick, Robert W. Livingston \& Joan C. Williams 2018. Work as a masculinity contest. Journal of Social Issues 74(3). 422-448. DOI: $10.1111 /$ josi.12289

Bonnes, Stephanie 2017. The bureaucratic harassment of U.S. servicewomen. Gender \& Society 31(6). 804-829. DOI: 10.1177/0891243217736006

Britton, Dana M. 2017. Beyond the chilly climate. The salience of gender in women's academic careers. Gender \& Society 31(1). 5-27. DOI: 10.1177/0891243216681494

Brownson, Connie. 2014. The battle for equivalency: Female US Marines discuss sexuality, physical fitness, and military leadership. Armed Forces \& Society 40(4). 765-788. DOI: $10.1177 / 0095327 X 14523957$

Carreiras, Helen. 2006. Gender and the military: Women in the armed forces of Western democracies. Routledge.

Collins Hill, Patricia. 2000. Black feminist thought: Knowledge, consciousness, and the politics of empowerment (2nd edn.). Routledge.

Connell, Robert W. 1987. Gender and power: Society, the person, and sexual politics. Stanford University Press.

Connell, Raewyn. 2002. Gender. Polity Press.

Crowley, Kacy \& Michelle Sandhoff. 2017. Just a girl in the Army: U.S. Iraq war veterans negotiating femininity in a culture of masculinity. Armed Forces \& Society 43(2). 221237. DOI: $10.1177 / 0095327 X 16682045$

Denzin, Norman K. \& Yvonna S. Lincoln. 2000. Introduction: The discipline and practice of qualitative research. In Norman K. Denzin \& Yvonna S. Lincoln (eds.), Handbook of qualitative research, Sage. 1-32.

Disler, Edith A. 2008. Language and gender in the military: Honorifics, narrative, and ideology in Air Force talk. Cambria Press.

Drew, Paul \& Elizabeth Holt. 1988. Complainable matters: The use of idiomatic expressions in making complaints. Social Problems 35(4). 398-417. DOI: 10.2307/800594

Dunivin, Karen O. 1991. Adapting to a man's world: United States Air Force female officers. Defense Analysis 7(1). 97-103, DOI: 10.1080/07430179108405487

Eckert, Penelope \& Sally McConnell-Ginet. 2003. Language and gender. Cambridge University Press.

Enloe, Cynthia. 2010. Nimo's war, Emma's war: Making feminist sense of the Iraq war. University of California Press.

Enloe, Cynthia. 2017. On feminist international relations, patriarchy, women's transnational organizing and on militarization. Interview by Mila O'Sullivan. https://www.youtube.com/watch?v=eDsX2d19hn0

Epstein, Cynthia. 1981. Women in the law. Anchor.

Foley, Meraiah, Sarah Oxenbridge, Rae Cooper \& Marian Baird. 2020. 'I'll never be one of the boys': Gender harassment of women working as pilots and automotive tradespeople. Gender, Work \& Organization. AOP. DOI: 10.1111/gwao.12443 
Gardner, Rod. 2004. Conversation analysis. In Alan Davies \& Catherine Elder (eds.), The handbook of applied linguistics, 262-284, Blackwell. DOI: 10.1002/9780470757000.ch10

Goffman, Erving. 1959. The presentation of self in everyday life. Doubleday.

Heinecken, Lindy. 2017. Conceptualizing the tensions evoked by gender integration in the military: The South African case. Armed Forces \& Society 43(2). 202-220. DOI: $10.1177 / 0095327 X 16670692$

Herbert, Melissa S. 1998. Camouflage isn't only for combat. Gender, sexuality, and women in the military. New York University Press.

Heritage, John. 2010. Questioning in medicine. In Alice Freed \& Susan Ehrlich (eds.), Why do you ask? The function of questions in institutional discourse, Oxford University Press. 42-68. DOI: 10.1093/acprof:oso/9780195306897.003.0003

Herring, Susan C. 2004. Computer-mediated discourse analysis: An approach to researching online behavior. In Sasha A. Barab, Rob Kling \& James H. Gray (eds.), Learining in doing. Designing for virtual communities in the service learning, Cambridge University Press. 338-376.

Howard, John W. III \& Laura C. Prividera. 2004. Rescuing patriarchy or saving "Jessica Lynch": The rhetorical construction of the American woman soldier. Women \& Language 27(2). 89-97.

Howard, John W. III \& Laura C. Prividera. 2008. The fallen woman archetype: Media representations of Lynndie England, gender, and the (ab)uses of U.S. female soldiers. Women's Studies in Communication 31(3). 287-311.

DOI: $10.1080 / 07491409.2008 .10162544$

Jefferson, Gail. 2004. Glossary of transcript symbols with an introduction. In Gene H. Lerner (ed.), Conversation Analysis: Studies from the first generation, John Benjamins. 13-31. DOI: 10.1075/pbns.125.02jef

Kanter, Rosabeth M. 1977a. Men and women of the corporation. Basic Books.

Kanter, Rosabeth M. 1977b. Some effects of proportions on group life: Skewed sex ratios and responses to token women. American Journal of Sociology 82(5). 965-990. DOI: $10.1086 / 226425$

Kendall, Shari \& Deborah Tannen. 1997. Gender and language in the workplace. In Ruth Wodak (ed.), Sage studies in discourse. Gender and discourse, Sage. 81-105.

King, Anthony C. 2013. The female soldier. Parameters 43(2). 13-25.

King, Anthony C. 2015. Women warriors: Female accession to ground combat. Armed Forces \& Society 41(2). 379-387. DOI: 10.1177/0095327X14532913

King, Anthony C. 2016. The female combat soldier. European Journal of International Relations 22(1). 122-143. DOI: $10.1177 / 1354066115581909$

King, Anthony C. 2017. Gender and close combat roles. In Rachel Woodward \& Claire Duncanson (eds.), The Palgrave international handbook of gender and the military, Palgrave Macmillan. 305-317. DOI: 10.1057/978-1-137-51677-0_19

Kitzinger, Celia. 2000. How to resist an idiom. Research on Language and Social Interaction 33(2). 121-154. DOI: 10.1207/S15327973RLSI3302_1

Lazar, Michelle M. 2014. Feminist critical discourse analysis: Relevance for current gender and language research. In Susan Ehrlich, Miriam Meyerhoff \& Janet Holmes (eds.), Handbook of language, gender, and sexuality (2nd edn.), Wiley. 180-199.

DOI: 10.1002/9781118584248.ch9 
Lester, Jessica N. \& Michelle O'Reilly. 2016. The history and landscape of conversation and discourse analysis. In Jessica N. Lester \& Michelle O'Reilly (eds.), The Palgrave handbook of adult mental health, Palgrave Macmillan. 23-44. DOI: 10.1057/9781137496850_2

Mackenzie, Megan. 2015. Beyond the band of brothers. The US military and the myth that women can't fight. Cambridge University Press.

Moore, Brenda L. 1991. African American women in the U.S. military. Armed Forces \& Society 17(3). 363-384. DOI: 10.1177/0095327X9101700303

Ostermann, Ana C. 2017. 'No mam. You are heterosexual': Whose language? Whose sexuality? Journal of Sociolinguistics 21(3). 348-370. DOI: 10.1111/josl.12240

Pawelczyk, Joanna. 2011. Talk as therapy. Psychotherapy in a linguistic perspective. De Gruyter Mouton. DOI: 10.1515/9781934078679

Pawelczyk, Joanna. 2017. 'It wasn't because a woman couldn't do a man's job': Uncovering gender ideologies in the context of interviews with American female and male war veterans. Gender and Language 11(1). 121-150.

Perez, Alycia L.U. \& Tatiana V. Strizhko. 2018. Minority representation, tokenism, and well-being in army units. Military Psychology 30(5). 449-463. DOI: $10.1080 / 08995605.2018 .1482184$

Pomerantz, Anita. 1986. Extreme case formulations: A way of legitimizing claims. Human Studies 9. 219-229. DOI: $10.1007 / \mathrm{BF} 00148128$

Potter, Jonathan. 1996. Representing reality: Discourse, rhetoric and social construction. Sage. DOI: $10.4135 / 9781446222119$

Prividera, Laura C. \& John W. Howard III. 2014. Repealing the direct combat exclusion rule: Examining the ongoing "invisible war"” against women soldiers. Women \& Language 37(1). 115-120.

Reinharz, Shulamit \& Susan E. Chase. 2001. Interviewing women. In Jaber F. Gubrium \& James A. Holstein (eds.), Handbook of interview research. Context and method, Sage. 221-238. DOI: 10.4135/9781412973588.n15

Rustad, Michael. 1982. Women in khaki: The American enlisted woman. Praeger.

Sacks, Harvey, Emanuel A. Schegloff \& Gail Jefferson. 1974. A simplest systematic for the organization of turn-taking in conversation. Language 50(4). 696-735. DOI: $10.2307 / 412243$

Sasson-Levy, Orna. 2003. Feminism and military gender practices: Israeli women soldiers in "masculine" roles. Sociological Inquiry 73(3). 440-465.

DOI: 10.1111/1475-682X.00064

Shaw, Sylvia. 2006. Governed by the rules? The female voice in parliamentary debates. In Judith Baxter (ed.), Speaking out. The female voice in public context, Palgrave. 81-102.

Silverman, David. 2001. The construction of 'delicate' objects in counselling. In Margaret Wetherell, Stephanie Taylor \& Simeon J. Yates (eds.), Discourse theory and practice: A reader, Sage. 119-137.

Sjoberg, Laura. 2010. Women fighters and the 'beautiful soul' narrative. International Review of the Red Cross 92(887). 53-68. DOI: 10.1017/S181638311000010X

Sjoberg, Laura, Grace Cooke \& Stacy Reiter Neal. 2011. Introduction. Women, gender and terrorism. In Laura Sjoberg \& Caron E. Gentry (eds.), Women, gender, and terrorism, University of Georgia Press. 1-27. 
Stokoe, Elizabeth. 2010. 'I'm not gonna hit a lady': Conversation analysis, membership categorization and men's denials of violence towards women. Discourse and Society 21(1). 59-82. DOI: $10.1177 / 0957926509345072$

Stokoe, Elizabeth. 2012. Moving forward with membership categorization analysis: Methods for systematic analysis. Discourse Studies 14(3). 277-303. DOI: $10.1177 / 1461445612441534$

Sue, Derald Wing. 2010. Microaggressions in everyday life. Race, gender, and sexual orientation. Wiley.

SWAN = Service Women's Action Network. 2019. Women in the military: Where they stand (10th edn.). SWAN.

Trobaugh, Elizabeth M. 2018. Women, regardless. Understanding gender bias in U.S. military integration. Joint Force Quarterly 88: 46-53.

Walsh, Claire. 2001. Gender and discourse: Language and power in politics, the church and organizations. Longman.

Weatherall, Ann, Maria Stubbe, Jane Sunderland \& Judith Baxter. 2010. Conversation analysis and critical discourse analysis in language and gender research: Approaches in dialogue. In Janet Holmes \& Meredith Marra (eds.), Femininity, feminism and gendered discourse, Cambridge Scholars. 213-243.

Yoder, Janice D. 1991. Rethinking tokenism: Looking beyond numbers. Gender \& Society 5(2) 178-192. DOI: 10.1177/089124391005002003

Yoder, Janice D. 2002. 2001 Division 35 Presidential Address: Context matters: Understanding tokenism processes and their impact on women's work. Psychology of Women Quarterly 26(1). 1-8. DOI: 10.1111/1471-6402.00038

Yoder, Janice D. \& Alycia L. U. Perez. 2013. Tokenism. In Vicky Smith (ed.), Sociology of work: An encyclopaedia, Sage. 884-886. 